Reprod. Nutr. Dévelop., 1988, 28 (2 A), 275-292.

\title{
Effects of dietary $\alpha$-linolenic acid deficiency during pregnancy and lactation on lipid fatty acid composition of liver and serum in the rat
}

\author{
Ph. GUESNET, G. PASCAL (*), G. DURAND
}

Station de Recherches de Nutrition,

(*) Laboratoire des Sciences de la Consommation, I.N.R.A., 78350 Jouy-en-Josas, France.

Summary. The effects of a dietary $\alpha$-linolenic acid (18:3n-3) deficiency on lipid fatty acid composition of the liver and serum of lactating rats have been studied during three gestations and over three generations. These females were compared to corresponding females which remained sterile.

Two lots of female rats received, respectively, a diet containing lipids either in the form of $1.50 \mathrm{~g}$ of sunflower oil per $100 \mathrm{~g}$ of diet (deficient diet) or as $1.87 \mathrm{~g}$ of soya oil per $100 \mathrm{~g}$ of diet (control diet). Both diet contained the same amount of linoleic acid (18:2 n-6), i.e. $940 \mathrm{mg} / 100 \mathrm{~g}$ of diet, but the sunflower diet supplied 43 times less $18: 3 \mathrm{n}-3$ than the soja diet, or $3 \mathrm{mg}$ vs $130 \mathrm{mg} / 100 \mathrm{~g}$ of diet.

Results show that successive gestations appeared to be more efficient means of depleting material n-3 PUFA (1) stores than successive generations. The $18: 3 n-3$ deficient diet caused a considerable decrease in the level of $n-3$ polyunsaturated fatty acids $(n-3$ PUFA) in liver and serum lipids, and particularly of $22: 6 \mathrm{n}-3$. This decline was compensated by an increase in the level of $n-6$ polyunsaturated fatty acids ( $n-6$ PUFA), and particularly by a very high augmentation of $22: 5 n-6$.

The ratio n-6 PUFA/n-3 PUFA in liver phospholipids and in serum lipids was a good index of the adequacy of dietary n-3 PUFA supply.

However, the ratio $22: 5 n-6 / 22: 6 n-3$ was a finer index. This ratio appeared to be a reliable index of dietary n-3 PUFA deficiency when it was higher than 1 in serum lipids of a fasting animal.

The proportion of $22: 5 n-6$ as well as the ratios $n-6 / n-3$ and $22: 5 n-6 / 22: 6 n-3$, were also increased in the liver phospholipids of lactating females receiving the soya oil diet; this suggested that a supply of $130 \mathrm{mg} / 100 \mathrm{~g}$ of diet, corresponding to a ratio of $n-6 / n-3=7.2$, was not sufficient for these rats during pregnancy and lactation.

A supply of $200 \mathrm{mg}$ of $n-3$ PUFA $/ 100 \mathrm{~g}$ of diet, corresponding to a ratio of $n-6 / n-3=5$, is recommended for these animals.

\section{Introduction.}

Fatty acids in the n-3 series, of which $\alpha$-linolenic acid is the main one, are usually found in phospholipids and thus in cellular and subcellular membranes of mammals (Crawford et al., 1969, 1970a, b ; Crawford and Woodford, 1971 ; Gudbjarnason and Halgrimsson, 1976 ; Setchell, 1978).

(1) Abbreviations : saturated fatty acids = SFA ; monounsaturated fatty acids = MUFA ; polyunsaturated $n-6$ fatty acids $=n-6$ PUFA ; polyunsaturated $n-3$ fatty acids $=n-3$ PUFA. 
These fatty acids, mostly composed of docosahexaenoic acid (22:6n-3), are very abundant in nervous tissue membranes, particularly in brain (Svennerholm, 1968 ; Alling et al., 1972 ; Galli et al., 1971 ; Eddy and Harman, 1975 ; Cohen and Bernsohn, 1978 ; Bourre et al., 1984) and retina (Anderson and Maude, 1972 ; Benolken et al., 1973 ; Tinoco et al., 1977 ; Aveldano de Caldironi et al., 1981 ; for review, see Tinoco, 1982).

They are also found in serum lipids in the form of $20: 5 n-3$ and $22: 6 n-3$. As a precursor of prostanoids of the $n-3$ series, $20: 5 n-3$ plays an important role in the regulation of platelet aggregation and prevents the formation of thrombi (Dyerberg et al., 1978 ; Siess et al., 1980 ; Needleman et al., 1979 ; Budowski et al., 1980 ; Sinclair, 1981). Moreover, n-3 PUFA are powerful hypocholesterolemic and hypotriglyceridemic agents (Nordoy, 1965 ; Peifer, 1966 ; Dyerberg et al., 1975 ; Harris et al., 1983 ; Fehily et al., 1983 ; Durand et al., 1985). When the diet is deficient in these n-3 PUFA, $n-3$ fatty acids are usually replaced by n-6 fatty acids or, more strictly speaking, most of the $22: 6 n-3$ is replaced by $22: 5 n-6$ (Galli et al., 1971, 1974 ; Cohen and Bernsohn, 1978 ; Tinoco et al., 1978 ; Menon and Dhopeshwarkar, 1981 ; Nouvelot et al., 1983a,b ; Bourre et al., 1984 ; Youyou et al., 1986).

However, when this occurs, the physiological status is not normal, resulting in an alteration of the electroretinogram (ERG) (Wheeler et al., 1975; Neuringer et al., 1984, 1986a, b ; Nouvelot et al., 1985), higher neonatal mortality (Sinclair and. Crawford, 1973 ; François et al., 1980 ; Guesnet et al., 1986), decreased learning ability (Galli et al., 1975 ; Lamptey and Walker, 1978), changes in enzyme activities which may alter membrane physiology (Bernsohn and Spitz, 1974 ; Sun and Sun, 1974 ; McMurchie and Raison, 1979 ; Flier et al., 1985), and neurological disorders (Holman et al., 1982).

Now, membrane structures, and particularly those of the nervous. system, develop intensely during the foetal period and lactation (Sinclair and Crawford, 1972 ; Crawford et al., 1981 ; Bourre, 1984 ; Menon and Dhopeshwarkar, 1982). Moreover, the return to a normal lipid fatty acid composition in the membranes is very slow when a sufficient amount of $n-3$ PUFA is supplied to previously deprived animals (Youyou et al., 1986).

All these data show that it is important to correctly estimate the $n-3$ PUFA requirement in females during gestation and lactation.

In a previous paper, we studied the effects of maternal dietary $\alpha$-linolenic acid deficiency on neonatal survival of the young (Guesnet et al., 1986).

The aim of the present work was to show the effects of dietary $\alpha$-linolenic acid deficiency on lipid fatty acid composition in the liver and serum of female rats after pregnancy-lactation and to obtain information on the $\alpha$-linolenic acid requirements of these animals. 


\section{Material and methods.}

\section{Animals.}

The experimental designs used have been described by Guesnet et al. (1986) (fig. 1).

\section{a) Successive gestations}

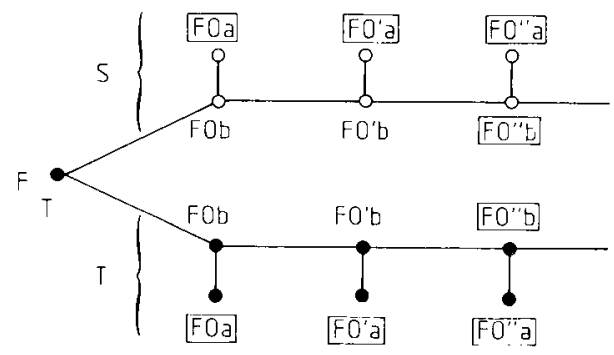

b) Successive generations

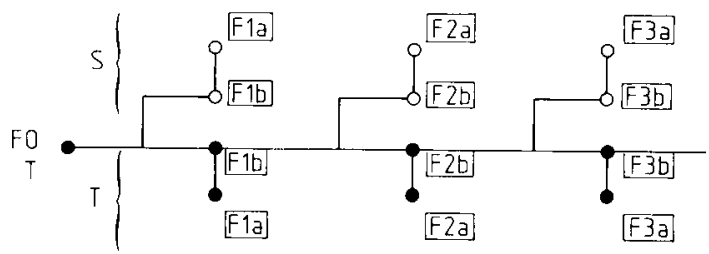

FIG. 1. - Experimental designs.

- : sunflower oil diet (T) ; $($ : soya oil diet (S) ; a : sterile females ; b : fertile females.

Design I. Successive gestations. - From weaning, about 100 female Wistar rats (F0) received a semi-synthetic diet (table 1 ) in which the lipids were supplied exclusively by $1.5 \%$ sunflower oil poor in $\alpha$-linolenic acid $(0.2 \%)$. At 8 weeks of age, or 2 weeks before mating, they were divided into two groups; one continued to receive the sunflower diet and the other was given a diet in which the sunflower oil was replaced by $1.87 \%$ of soya oil containing a high level of $\alpha$ linolenic acid $(7.4 \%)$.

Both diets contained $940 \mathrm{mg}$ of linoleic acid/100 $\mathrm{g}$ diet, but the sunflower diet had only $3 \mathrm{mg}$ of $\alpha$-linolenic acid while the soya diet contained $130 \mathrm{mg}$ (table 2).

The FO rats were mated at 10 weeks and the gravid ones FOb again at 18 weeks at the end of lactation ; those which had a second litter FO' b, nursed it and were then mated a third time at 26 weeks. We thus obtained females which had three successive gestations (F0"b). 
TABLE 1

Diet composition (per $\mathrm{kg}$ ).

\begin{tabular}{|c|c|c|}
\hline & $\begin{array}{c}\text { Soya oil (S) } \\
\text { diet }\end{array}$ & $\begin{array}{c}\text { Sunflower oil }(T) \\
\text { diet }\end{array}$ \\
\hline Casein (1) & 220 & 220 \\
\hline DL Methionine (1) & 1.6 & 1.6 \\
\hline Cellulose (1) .... & 20 & 20 \\
\hline Starch (1) .. & 459.7 & 463.4 \\
\hline Saccharose (1) ... & 230 & 230 \\
\hline Oil ......... & 18.7 & 15.0 \\
\hline Vitamin mixture. & 10 & 10 \\
\hline Mineral mixture (2) & 40 & 40 \\
\hline
\end{tabular}

(1) United States Biochemical Corp., Cleveland (USA). The vitamin mixture used is the vitamin diet for fortification mixture.

(2) Composition of the mineral mixture/100 g: $\mathrm{CaHPO}_{4}, 2 \mathrm{H}_{2} \mathrm{O}, 38.0 ; \mathrm{K}_{2} \mathrm{HPO}_{4}, 24.0: \mathrm{CaCO}_{3}$, $18.1 ; \mathrm{NaCl}, 7.0 ; \mathrm{MgO}, 2.0 ; \mathrm{MgSO}_{4}, 7 \mathrm{H}_{2} \mathrm{O}, 9.0 ; \mathrm{FeSO}_{4}, 7 \mathrm{H}_{2} \mathrm{O}, 0.7 ; \mathrm{ZnSO}_{4}, \mathrm{H}_{2} \mathrm{O}, 0.5: \mathrm{MnSO}_{4}$. $\mathrm{H}_{2} \mathrm{O}, 0.5$ : $\mathrm{CuSO}_{4}, 5 \mathrm{H}_{2} \mathrm{O}, 0.1 ; \mathrm{NaF}, 0.1 ; \mathrm{Al}_{2}\left\langle\mathrm{SO}_{4}\right\}_{3} \mathrm{~K}_{2} \mathrm{SO}_{4}, 24 \mathrm{H}_{2} \mathrm{O}, 0.02 ; \mathrm{KI}, 0.008 ; \mathrm{CoCO}_{3}, 0.008$; $\mathrm{Na}_{2} \mathrm{SeO}_{3}, 5 \mathrm{H}_{2} \mathrm{O}, 0.001$.

\section{TABLE 2}

Fatty acid composition of dietary lipids.

\begin{tabular}{|c|c|c|}
\hline \multirow[b]{2}{*}{ Fatty acids } & \multicolumn{2}{|c|}{ Diet } \\
\hline & Soya oil (S) & Sunflower oil $(T)$ \\
\hline $\begin{array}{l}\text { C14 : } 0 \\
\text { C16:0 } \\
\text { C17 : } 0 \\
\text { C18 : } 0 \\
\text { C20 : } 0 \\
\text { C22 : } 0\end{array}$ & $\begin{array}{r}0.3 \\
10.1 \\
0.2 \\
5.6 \\
0.4 \\
0.5\end{array}$ & $\begin{array}{l}0.3 \\
6.4 \\
- \\
3.9 \\
0.3 \\
0.7\end{array}$ \\
\hline$\Sigma$ saturated & 17.2 & 11.6 \\
\hline $\begin{array}{l}\text { C16: } 1 \\
\text { C18 }: 1 \\
\text { C20 }: 1\end{array}$ & $\begin{array}{r}\overline{21.4} \\
0.3\end{array}$ & $\begin{array}{r}0.2 \\
21.6 \\
0.2\end{array}$ \\
\hline$\Sigma$ monounsaturated & 21.7 & $\overline{22.0}$ \\
\hline C18 : $2 n-6$ & 53.5 & 66.4 \\
\hline C18: $3 n-3$ & 7.4 & 0.2 \\
\hline $\begin{array}{l}\text { Fatty acids } / 100 \mathrm{~g} \text { of diet : } \\
\text { C18 : } 2 \mathrm{n}-6(\mathrm{mg}) \\
\text { C18:3 } \mathrm{n}-3(\mathrm{mg})\end{array}$ & $\begin{array}{l}940.0 \\
130.0\end{array}$ & $\begin{array}{r}936.0 \\
3.0\end{array}$ \\
\hline$n-6 / n-3$ & 7.2 & 333.4 \\
\hline
\end{tabular}

Dietary lipid fatty acid composition was analysed by gas chromatography of fatty acid methyl esters in the following conditions : Packard model 427 chromatograph ; glass capillary column ; stationary phase FFAP; carrier gas pressure $\mathrm{H}_{2}: 0.6$ bar ; temperature : $190^{\circ} \mathrm{C}$; detection by flame ionization. 
One group of 6 females was killed at the end of the third lactation (group F0"b). This lot was compared to lots of 6 sterile females each of the stages studied (FOa : 0 gestation ; F0' a : 1 gestation ; Fo"a : 2 gestations).

Design /1. Successive generations. - In each generation 40 to 50 females of the sunflower lineage (T) were divided into two groups at 8 weeks of age; one was kept on the sunflower diet and the other was given the soya diet (S). These rats were then mated at 10 weeks of age.

Groups of 6 females each were killed at the end of lactation along with 6 sterile littermates.

In both designs, the females remained with males during one sexual cycle (4 days) ; the latter were stock-breeding rats receiving a commercial diet. Twenty day later, the gravid females were put into individual cages. The third day postpartum, the litters were equalized to 10 pups each, except the F1 and F3 litters which could not be equalized to more than 7 and 8 pups each, respectively. The litters were weaned when 21 days old. Feed intake measured during gestation and lactation has been shown to be independent of the diet during both periods (Guesnet et al., 1986).

The rats were killed by bleeding. The blood of each lot was pooled and centrifuged after coagulation. The liver, heart, brain and eyes were taken, weighed and pooled; the serum and organs were freeze-dried and stored at $-80^{\circ} \mathrm{C}$.

The fatty acid composition of the brain, eyes and heart of the different groups will be published in another article.

\section{Analytical methods.}

Total lipids were extracted by the method of Folch et al. (1957). Phospholipids and neutral lipids were separated using the method of Borgström (1952). Serum fatty acid composition was determined after direct saponification under reflux (Gandemer et al., 1980).

Fatty acid composition was determined by gas-liquid chromatography (Packard 427) of methyl esters on a glass capillary column ( $D=0.3 \mathrm{~mm} ; \mathrm{L}=$ $45 \mathrm{~m}$; phase = FFAP $0.5 \%$; flame ionization detector).

\section{Results.}

In general, for a given diet and for females which had the same physiological status, the factors studied did not change significantly over successive generations or gestations. Only some results on F0" females, which had 3 successive gestations, showed significant modification.

Thus, our analysis included mostly comparisons (1) between the effects of the two diets on females which had the same physiological status and (2) between females at the end of lactation and the corresponding ones which remained sterile to determine the effect of reproduction. 


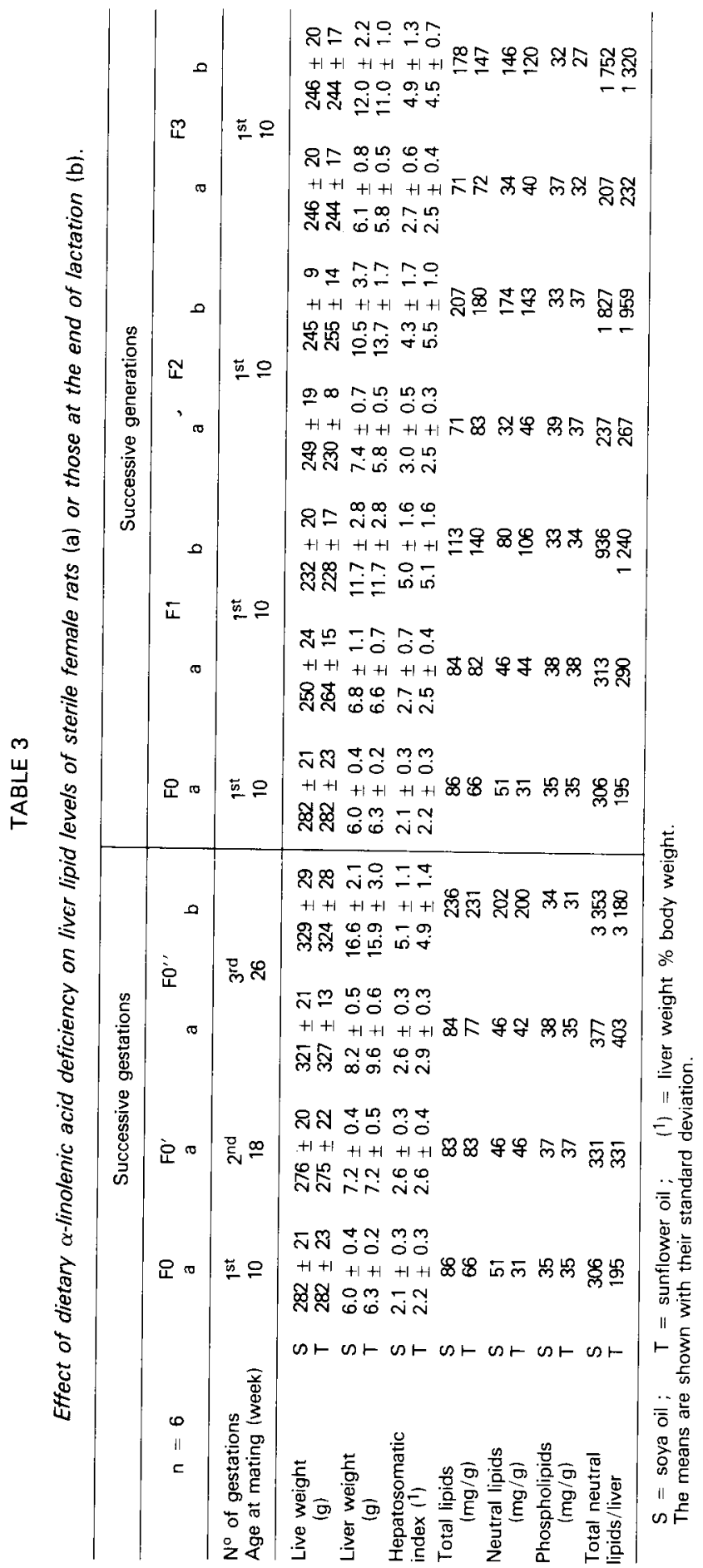




\section{Female weight (table 3).}

Neither the number of generations, lactation nor $\alpha$-linolenic acid deficiency had any effect on rat live weight ; this weight was related only to animal age, as shown by the higher weight of group $\mathrm{FO}^{\prime \prime}$.

\section{Liver.}

2.1. Fresh weight (table 3). - Liver weight was independent of diet. On the other hand, it was closely related to physiological status since it was about 2-fold higher in rats at the end of lactation than in the corresponding sterile females $(6$ to 8 vs 11 to $16 \mathrm{~g}$ ). The hepatosomatic index (liver weight \% body weight), which was about 2.5 in sterile rats, reached about 5.0 in females at the end of lactation.

2.2. Lipid level (table 3). - Liver total lipids also seemed to be independent of diet but was always higher in females at the end of lactation than in the sterile ones (mean: $78 \mathrm{mg} / \mathrm{g}$ vs $180 \mathrm{mg} / \mathrm{g}$ fresh tissue) $(\times 2.3)$. However, this difference was due exclusively to neutral lipids (mean : $42 \mathrm{mg} / \mathrm{g}$ fresh tissue in sterile rats vs $145 \mathrm{mg} / \mathrm{g}$ in those at the end of lactation) $(\times 3.5)$. Phospholipid level (about $35 \mathrm{mg} / \mathrm{g}$ fresh weight) was independent of diet and of physiological status. As compared to the whole liver, the livers of sterile females included 200 to $300 \mathrm{mg}$ of neutral lipids, while those of females at the end of lactation included 1,000 to $2,000 \mathrm{mg}$ or a mean 6-fold more. However, it should be noted that the animals which had three successive lactations (group F0"b) had a total hepatic content of neutral lipids which was greater than $3,000 \mathrm{mg}$ due to the high weight of the organ and its high concentration of that type of lipids.

\subsection{Fatty acid composition of liver lipids.}

\subsubsection{Phospholipids (table 4).}

a) SFA + MUFA. The SFA of liver phospholipids constituted 35 to $40 \%$ of all the phospholipids; they were primarily represented by palmitic (about $15 \%$ ) and stearic (20 to $25 \%$ ) acids. Neither $\alpha$-linolenic acid deficiency nor lactation had any significant effect on the level of these fatty acids in liver phospholipids.

In our experimental conditions, the proportion of MUFA in liver phospholipids varied between 8 and $20 \%$; their main element was oleic acid (C18 : $1 \mathrm{n}-9$ ) which alone represented more than $50 \%$ of this type of fatty acid. $\alpha$-linolenic acid deficiency in sterile animals had no effect on the mean MUFA level in liver phospholipids, but lactation caused a significant increase of these fatty acids ; this increase was slightly less in the sunflower $(11 \rightarrow 15 \%)$ than in the soya $(11 \rightarrow 17 \%)$ rats.

b) n-6 PUFA. n-6 PUFA are the most abundant constituents of liver phospholipids ; 37 to $48 \%$ of all the fatty acids belong to this family. Their total level was always higher in sunflower rats (about $46 \%$ ) than in soya ones (about 
(1)

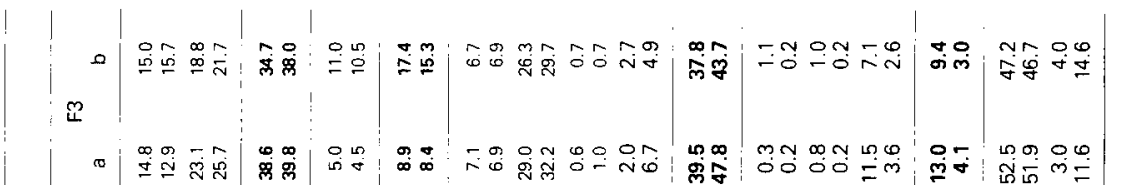

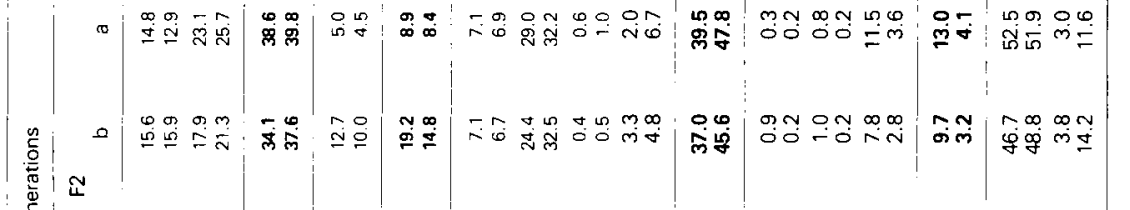

焉

⿹ I

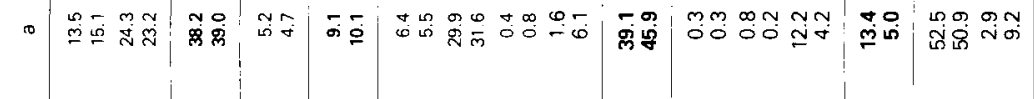

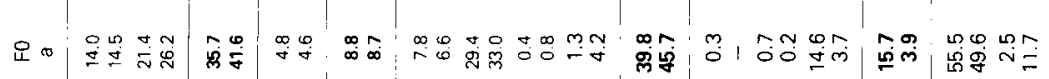

\begin{tabular}{|c|c|c|c|c|c|c|c|c|c|}
\hline & & $m 8$ & & & & & & & $8-$ \\
\hline م & 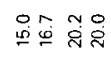 & 实焉 & $\stackrel{\circ}{\varrho}$ & 它是 & 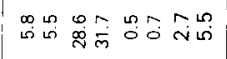 & $\begin{array}{l}\infty \\
\infty \\
\dot{m} \neq j\end{array}$ & 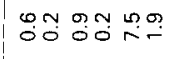 & कंजे & 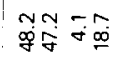 \\
\hline
\end{tabular}

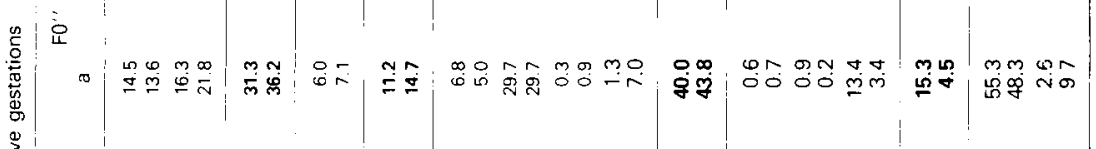

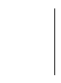


$38 \%)$. This overall superiority in these rats was due mostly to the constantly high, relative level of $22: 5 \mathrm{n}-6$; the rest was imputed to $20: 4 \mathrm{n}-6$ and $22: 4 \mathrm{n}$ 6. On the other hand, $18: 2$ n-6 was no longer abundant in sunflower rats, showing that it supplied longer-chain derivatives of its series when n-3 PUFA was deficient.

The level of $22: 5$ n- 6 was usually higher in soya females at the end of lactation than in the corresponding sterile ones; the reverse was true in sunflower animals.

c) n-3 PUFA. The level of n-3 PUFA in liver phospholipids varied considerably and according to diet and physiological status. In sterile females, this level was 13 to $16 \%$ with the soya diet and 4 to $5 \%$ with the sunflower diet; in females at the end of lactation, it was 9 to $10 \%$ with the soya diet and $3 \%$ with the sunflower regime. These variations in level were due to the three $n-3$ PUFA elements of liver phospholipids, i.e. $20: 5 n-3,22: 5 n-3$ and $22: 6 n-3$, but mostly to the latter $(90 \%)$ which is a basic component of membrane structure.

d) $n-6+n-3$ and $n-6 / n-3$. In spite of some fluctuations (FOa, FO"a), it cannot be affirmed that dietary $\alpha$-linolenic acid deficiency had an effect on overall PUFA level in liver phospholipid in either sterile females or those at the end of lactation. In general, n-6 PUFA, and particularly $22: 5 n-6$, compensated for the lack of $22: 6 \mathrm{n}-3$. However, lactation caused a decrease in this level in both series of rats $(52 \rightarrow 47 \%)$; this decrease was compensated by an increase in the MUFA level (see above).

In sterile females, the $n-6 / n-3$ ratio was about 3 in soya group phospholipids and about 11 in sunflower group phospholipids ; in rats at the end of lactation, this ratio was about 4 for the first group and 15 for the second.

\subsubsection{Neutral lipids (table 5).}

a) SFA and MUFA. The SFA constituted 30 to $40 \%$ of the total fatty acids of liver neutral lipids, or slightly less than in the phospholipids. These fatty acids were represented mostly by palmitic acid ( 85 to $90 \%$ ).

The SFA level was not modified by $18: 3 n-3$ deficiency in sterile animals but increased slightly and independently of diet at the end of lactation $(33 \rightarrow 38 \%)$.

The MUFA were the most abundant in liver neutral lipids, forming 47 to $60 \%$ of all the fatty acids in this type of lipids. As in phospholipids, the dominant element was oleic acid (75 to $90 \%$ of total MUFA).

As in phospholipids, the MUFA level was unaffected by dietary $\alpha$-linolenic acid deficiency in sterile females but was always higher at the end of lactation (mean : $50 \rightarrow 58 \%$ ).

b) $n-6$ PUFA. This group of fatty acids was found in limited levels in liver neutral lipids $(2.4$ to $21.2 \%)$.

In sterile rats, the n-6 PUFA level was not significantly influenced by diet, but it was still slightly increased in sunflower animals.

In rats at the end of lactation, diet had no influence but the effect of lactation was considerable because the mean levels of these PUFA dropped from 


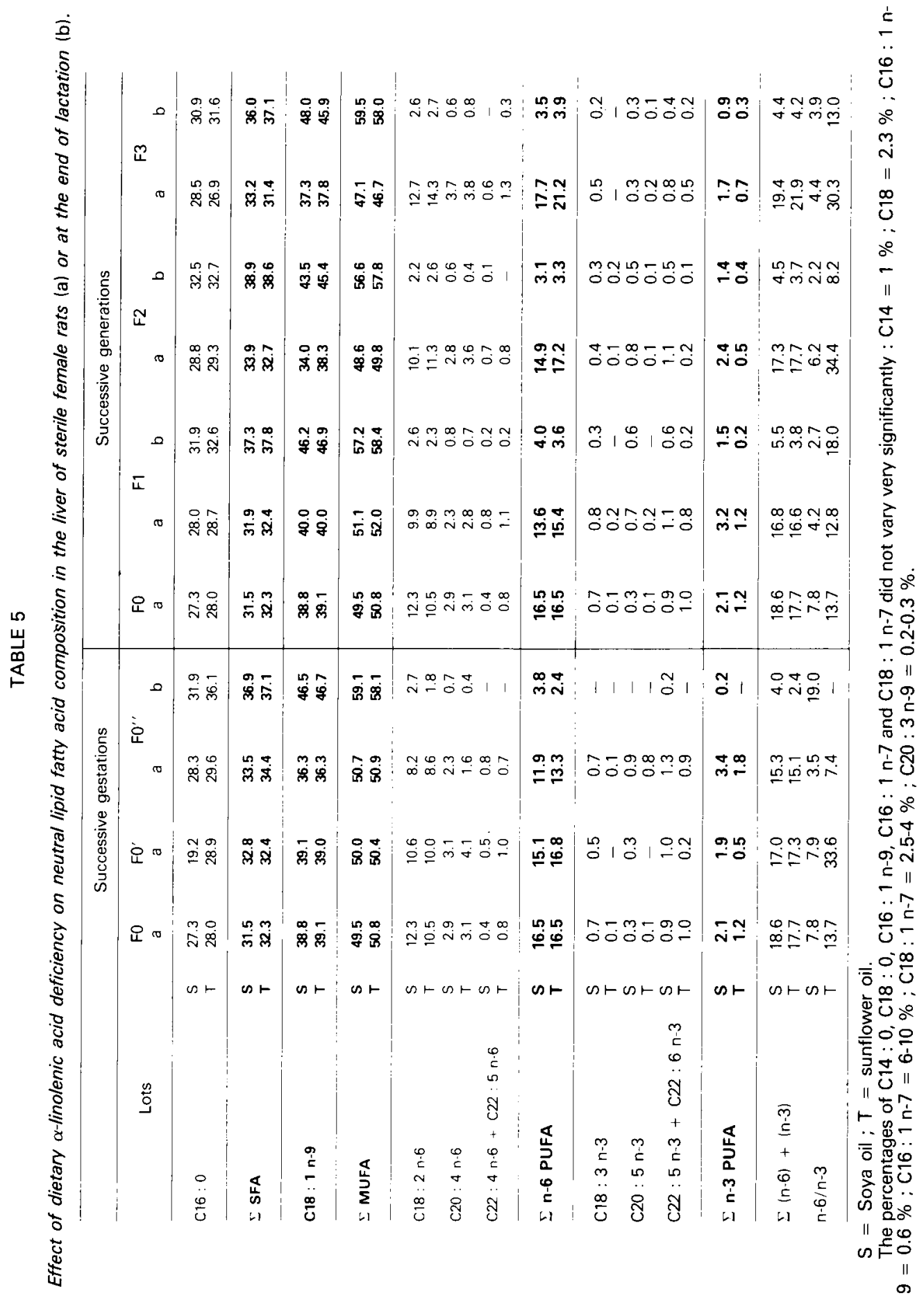


16 to $3.5 \%$. The mean levels of all the fatty acids of this series varied : $18: 2 n-6$ dropped from 10.5 to $2.4 \% ; 20: 4 \mathrm{n}-6$ from 2.9 to $0.6 \%$; and the sum of $22: 4 n-6+22: 5 n-6$ from $0.8 \%$ to practically zero.

c) $n-3$ PUFA. The proportion of n-3 PUFA in neutral lipids was influenced by dietary deficiency of $18: 3 n-3$ in both groups of rats.

While the $18: 3 \mathrm{n}-3$ level was about $2.5 \%$ in sterile soya females, it remained at about $1 \%$ in the corresponding sunflower rats. At the end of lactation, this level decreased to $1-1.5 \%$ in the soya females and to less than $0.5 \%$ in the sunflower ones.

d) $n-6+n-3$ and $n-6 / n-3$. In sterile rats, dietary deficiency did not significantly change the level of total PUFA, considering the low percentage of $n$ 3 PUFA in relation to n-6 PUFA and the slight progression of the latter in sunflower females.

In rats at the end of lactation, total PUFA were considerably lower in soya rats $(17 \rightarrow 4.6 \%)$ and in sunflower rats $(18 \rightarrow 3.5 \%)$; this total was not related to $18: 3$ n-3 deficiency.

Given the fact that the proportion of n-3 PUFA in neutral lipids was often very low, it was difficult to obtain a precise analysis of these fatty acids; the result was relative large errors in their estimation and thus wide variability of the $n-6 / n-3$ ratio. The ratio was always higher in sunflower females than in soya ones with the same physiological status; moreover, it was usually higher in sterile rats than in those at the end of lactation due to preferential mobilization of n-3 PUFA.

\section{Fatty acid composition of total serum lipids (table 6).}

a) SFA and MUFA. Neither diet nor lactation has any effect on the SFA level in serum lipids (about $33 \%$ ). These fatty acids were represented mostly by palmitic and stearic acids; contrary to that observed in liver phospholipids, palmitic acid was more abundant.

Total serum lipids included 20 to $30 \%$ of MUFA, the main one being oleic acid. In sterile females, diet had no effect on these fatty acids.

Lactation caused a slight increase in the MUFA level in soya females but none in sunflower animals, so that at the end of lactation, there were significant deviations between the two groups (28 to $29 \%$ in soya rats vs 22 to $24 \%$ in sunflower rats).

b) n-6 PUFA. In sterile females, diet had no effect on serum lipid levels in this type of fatty acids. However, $\alpha$-linolenic acid deficiency caused n-6 PUFA level in serum lipids of sunflower lactating rats to increase $(39 \rightarrow 42 \%)$, while this level in soya females decreased $(39 \rightarrow 35 \%)$; this resulted in a marked mean deviation between the two groups at the end of lactation.

As in liver phospholipids, arachidonic acid was by far the most abundant n- 6 PUFA and caused most of the variation in total n-6 PUFA level. The level of 22 : 5 n-6 was always higher in sunflower rats $(2 \%)$ while it varied between 0.5 and $1 \%$ in soya rats.

c) n-3 PUFA. The level of n-3 PUFA in serum lipids was 2 to 3 -fold less in 


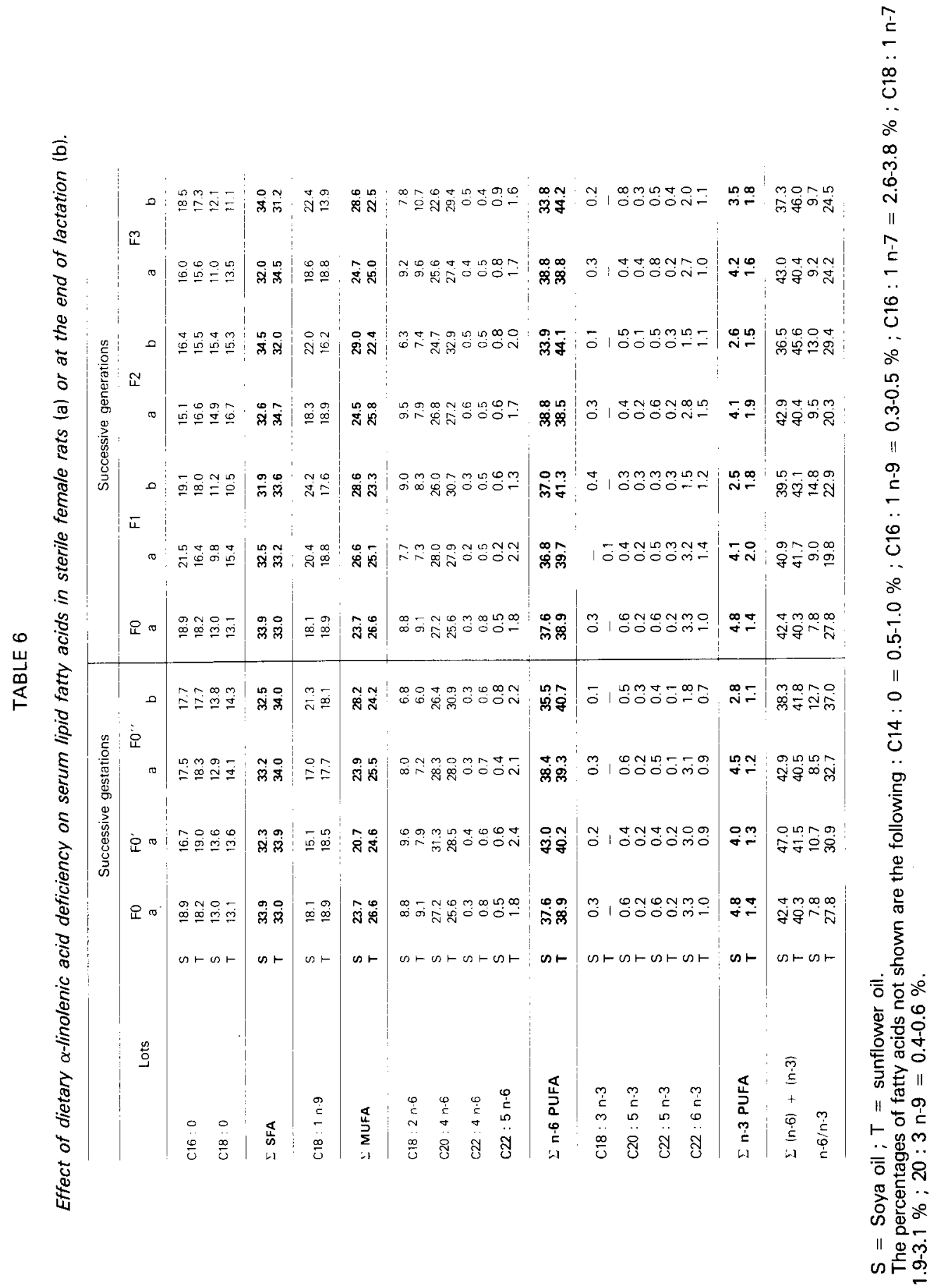


sterile sunflower rats than in their soya littermates $(2.5$ to $5 \%$ vs 1 to $2 \%)$. Lactation lowered this level in the latter from about 4.2 to $2.8 \%$, while it did not affect that level in sunflower rats (about $1.6 \%$ ).

$22: 6 n-3$ was again the most abundant n-3 PUFA; its level remained near $3 \%$ in sterile soya females. In rats with and $\alpha$-linolenic acid deficiency, the level of this fatty acid was about $1 \%$. In sunflower rats, $18: 3 n-3$ practically disappeared from serum lipids, while $20: 5 n-3$ and $22: 5 n-3$ always represented less than $0.5 \%$ of total fatty acids.

The ratio $22: 5 n-6 / 22: 6 n-3$ was always higher than 1 in sunflower rats and less than 0.5 in soya ones. In the latter, it was always higher in lactating rats than in sterile ones.

d) $n-6+n-3$ and $n-6 / n-3$. The total PUFA varied between 40 and $47 \%$, except in soya rats at the end of lactation, where it was always less than $40 \%$ due to the low level of n-6 PUFA and n-3 PUFA in serum lipids.

The ratio $n-6 / n-3$ varied between 8 and 10 in soya animals and between 20 and 30 in sunflower ones. Whatever the diet, it was always higher at the end of lactation than in the sterile littermates, but for different reasons : because of the decrease in n-3 PUFA with the soya diet and the increase of n-6 PUFA with the sunflower diet.

\section{Discussion.}

\section{Dietary $\alpha$-linolenic acid deficiency and liver lipids.}

Our data show that dietary $\alpha$-linolenic acid deficiency has no marked effect on liver size, including the hepatic hypertrophy of lactating rats that has been shown to be due to deep changes in lipid metabolism (Williamson, 1980). The hypertrophy we observed in this study at the end of lactation was accompanied by an increase in liver lipids, proportional to the increase in liver weight in the case of phospholipids, but much more than proportional $(\times 3.5)$ in the case of neutral lipids. This may be related to dietary intake which increased 3 -fold during lactation.

On the other hand, the $\alpha$-linolenic acid deficiency in sterile rats caused large changes in the fatty acid composition of liver lipids :

1.1. In phospholipids it caused the n-3 PUFA level to decrease, primarily due to the drop in $22: 6 \mathrm{n}-3$. This decrease was generally compensated by an augmentation in $n-6$ PUFA so that the sum of $n-6+n-3$ PUFA remained the same (about $52 \%$ of total fatty acids). This compensation required only a rather small increase in all the $n-6$ PUFA $(+20 \%)$, but this increase was considerable if we look at $22: 5 n-6$ ( $\times 2$ or 3 ). This confirms that $22: 5 n-6$ is a true index of $n$ 3 PUFA deficiency (Galli et al., 1974 ; Tinoco et al., 1979 ; Bourre et al., 1984 ; Youyou et al., 1986). 
The increase in n-6 PUFA and decrease in n-3 PUFA resulted in an augmentation of the ratio $n-6 / n-3$ which rose from about 3 in soya rats to about 13 in sunflower ones. According to Budowski and Crawford (1985), this values in soya rats would be normal but, as Galli et al. (1974) proposed, the ratio $22: 5 \mathrm{n}$ 6/22 : 6 n-3 can also be used as an index of n-3 PUFA deficiency, at least when the proportion of these two fatty acids is high enough to be precisely analysed.

In our experimental conditions, this ratio is about 0.1 to 0.4 in the controls and between 1 and 2 in deficient rats. Lactation also has its own effect on the respective levels of different types of PUFA in liver phospholipids; in fact, although it does not significantly change the overall n-6 PUFA level, it increased the $22: 5 n-6$ but decreased the $22: 6 n-3$ in soya rats. The lactation caused a two-fold increase in the $22: 5 n-6 / 22: 6 n-3$ ratio, indicating that the $\alpha$-linolenic acid supply of the soya diet was not sufficient for lactating females, either in absolute value (mg $18: 3 \mathrm{n}-3 / 100 \mathrm{~g}$ feed) and/or in relative value $(\mathrm{n}-6 / \mathrm{n}-3)$. This could explain why neonatal loss was still high (about $5 \%$ ) in the progeny of soya females (Guesnet et al., 1986).

On the contrary, in sunflower females, the ratio $22: 5 n-6 / 22: 6 n-3$ was not significantly changed by lactation (mean : $1.76 \mathrm{vs} 2.04$ ); this ratio seemed to reach a limit, beyond which the dam's physiology might be seriously altered.

1.2 In neutral lipids $\alpha$-linolenic acid deficiency produced modifications similar to those in phospholipids, with an increase in n-6 PUFA compensating a decrease in n-3 PUFA. However, PUFA in this type of lipids, no matter which series they belonged to, occured in such low proportions that the ratio $n-6 / n-3$ was not a precise index, and the ratio $22: 5 n-6 / 22: 6 n-3$ could not be used.

Still the most notable fact was the decrease in the proportion of PUFA in liver neutral lipids of lactating females, due to the uptake of these fatty acids by the mammary gland and to the increase of lipid neosynthesis in the liver.

The decrease of $n-6$ and especially n-3 PUFA levels was very significant at the end of the third consecutive lactation (group F0"). Successive gestations thus appeared to be a more efficient means of depleting maternal n-3 PUFA stores than successive generations.

\section{Dietary $\alpha$-linolenic acid deficiency and serum lipids.}

As expected, dietary $18: 3 n-3$ deficiency caused a decrease in the $n-3$ PUFA level in serum lipids that was marked by the clearance of $18: 3 n-3$ and a considerable decrease in $22: 6 \mathrm{n}-3$, which was the most abundant fatty acid of its series. When the diet was deficient in $18: 3 n-3$, this level remained at about $1 \%$, as previously reported by Durand et al. (1985).

But we did not expect that lactation would intensify the decrease in serum lipid n-3 PUFA only in the soya dams; it was as if the soya females could use their serum stores of this type of fatty acid to enrich their milk, while the sunflower females, having reached a minimal physiological threshold, in this respect, could not. A similar process is observed in the case of liver lipids.

Another remarkable fact was the change in serum lipid n-6 PUFA due to 
lactation; the level of these fatty acids, about equal in all the sterile females, tended to decrease in soya dams but increase in sunflower ones. While the decrease in $n-6$ PUFA in soya females can be easily explained by mammary gland uptake, it is difficult to understand their increase in sunflower rats. Mammary gland uptake of $n-3$ PUFA might be selective, resulting in an overload of $n-6$ PUFA.

In the serum lipids we analysed, the ratio $n-6 / n-3$ ranged between 20 and 40 . However, these rats were killed after fasting so the lipids contained no chylomicrons which could reflect the composition of dietary lipids; moreover, VLDL composition was not analysed separately. The fatty acid composition in the present study only furnishes an inexact picture of the lipids from which the mammary gland usually derives its fatty acids, i.e. the chylomicrons and the VLDL (Williamson, 1980). This ratio $n-6 / n-3$ might be higher in these fractions than in total serum lipids after fasting and would be more similar to the dietary value.

In any case, when the ratio $22: 5 n-6 / 22: 6 n-3$ is higher than 1 in a fasting animal, it appears to be a reliable index of dietary $n-3$ PUFA deficiency.

\section{Conclusion.}

Although in the last few years, and especially since the work of Holman et al. (1982), most authors recognize that n-3 PUFA are essential for mammals, few have proposed recommendations concerning the requirement of this type of fatty acids. In a recent review, Tinoco (1982) declared that « the dietary requirement, if any, for $n-3$ fatty acids in mammals and birds is unknown $"$. However, Holman et al. (1982) estimated this requirement in children as $0.54 \%$ of the caloric supply.

In female rats in reproduction, the results of a previous work (Guesnet et al., 1986) and of the present study seem to indicate that a supply of dietary n-3 PUFA equal to $130 \mathrm{mg} / 100 \mathrm{~g}$ diet and corresponding to a ratio of $n-6 / n-3=7.2$, is suboptimal.

From this, it appears that the ratio $n-6 / n-3$ in dietary lipids should be equal to or lower than 5 ; this corresponds to a minimal $\mathrm{n}-3$ PUFA supply of $200 \mathrm{mg} / 100 \mathrm{~g}$ diet, if the n-6 PUFA requirement is $1000 \mathrm{mg} / 100 \mathrm{~g}$ diet.

This analysis agrees with that of Budowski and Crawford (1985) based on a study of the value of the ratio $n-6 / n-3$ in phospholipids of different animal species and in human milk of different countries.

Reçu en mars 1987.

Accepté en novembre 1987

Résumé. Effets d'une déficience alimentaire en acide $\alpha$-linolénique pendant la gestation et la lactation sur la composition en acides gras des lipides du foie et du sérum chez le rat.

Les effets d'un régime alimentaire pauvre en acide $\alpha$-linolénique $(18: 3 n-3)$ sur la composition en acides gras des lipides du foie et du sérum sont étudiés chez des rattes allaitantes au cours de trois gestations et de trois générations. Ces femelles sont comparées à des femelles correspondantes restées stériles.

Pour cela, deux lots de rattes reçoivent respectivement un régime alimentaire dans lequel les lipides sont incorporés soit sous forme d'huile de tournesol, à raison de 1,50\% (régime déficient), soit sous forme d'huile de soja à raison de $1,87 \%$ (régime témoin). Les 
deux régimes apportent la même quantité d'acide linoléique (18:2 n-6) à savoir $940 \mathrm{mg} / 100 \mathrm{~g}$ d'aliment, mais le régime d'huile de tournesol apporte 43 fois moins de $18: 3$ $\mathrm{n}-3$ que le régime huile de soja, soit $3 \mathrm{mg} v s 130 \mathrm{mg} / 100 \mathrm{~g}$ d'aliment.

Les résultats montrent que la succession des gestations semble être un moyen plus efficace que la succession des générations pour conduire à un épuisement des réserves maternelles en acides gras polyinsaturés n-3 (AGPI $n-3$ ).

Dans les phospholipides hépatiques et les lipides sériques, le régime déficient en $18: 3$ $\mathrm{n}-3$ provoque une diminution considérable de la teneur des AGPI n-3, en particulier celle du 22 : $6 \mathrm{n}-3$. Cette diminution est compensée par une augmentation de la teneur des acides gras polyinsaturés $n-6$ (AGPI $n-6$ ), en particulier celle du $22: 5 n-6$. Le rapport AGPI n-6/ AGPI $n-3$ est un bon index de l'adéquation de l'apport alimentaire en AGPI $n-3$, mais le rapport $22: 5 n-6 / 22: 6 n-3$ est un index plus sensible.

La proportion de $22: 5 n-6$ par rapport à l'ensemble des acides gras, ainsi que les rapports $n-6 / n-3$ et $22: 5 n-6 / 22: 6 n-3$, sont également augmentés dans les phospholipides hépatiques des femelles allaitantes recevant le régime huile de soja : ceci suggère qu'un apport de $130 \mathrm{mg} / 100 \mathrm{~g}$ d'aliment, correspondant à un rapport $\mathrm{n}-6 / \mathrm{n}-3=7,2$, est insuffisant pour la ratte pendant la période de gestation-lactation.

Un apport de $200 \mathrm{mg}$ d'AGPI n-3/100 g d'aliment, correspondant à une valeur du rapport $n-6 / n-3=5$, est préconisé pour cet animal.

\section{Références}

ALLING C., BRUCE A., KARLSSON I., SAPIA O., SVENNERHOLM J., 1972. Effect of maternal essential fatty acid supply on fatty acid composition of brain, liver, muscle and serum in 21day old rats. J. Nutr., 102, 773-782.

ANDERSON R., MAUDE M., 1972. Lipids of ocular tissues. VIII. The effects of essential fatty acid deficiency on the phospholipids of the photoreceptor membranes of rat retina. Arch. Biochem. Biophys., 151, 270-276.

AVELDANO de CALDIRONI M., GIUSTO N., BAZAN N., 1981. Polyunsaturated fatty acids of the retina. Prog. Lipid Res., 20, 49-57.

BENOLKEN R., ANDERSON R., WHEELER T., 1973. Membrane fatty acids associated with the electrical response in visual excitation. Science, 182, 1253-1254.

BERNSOHN J., SPITZ F., 1974. Linoleic and $\alpha$-linolenic acid deficiency of some brain membranebound enzymes after lipid deprivation in rats. Biochem. Biophys. Res. Commun., 57, 293298.

BORGSTRÖM B., 1952. Chromatographie sur colonne. Séparation des différentes classes de lipides. Acta physiol. scand., 25, 101.

BOURRE J.-M., 1984. Origine des acides gras cérébraux. Synthèse in situ et apports nutritionnels. Rev. franc. Corps Gras, 31, 225-231.

BOURRE J.-M., PASCAL G., DURAND G., MASSON M., DUMONT O., PICIOTTI M., 1984. Alterations in the fatty acid composition of rat brain cells (neurons, astrocytes and oligodendrocytes) and of subcellular fractions (myelin and synaptosomes) induced by a diet devoid of n-3 fatty acids. J. Neurochem., 43, 342-348.

BUDOWSKI P., HAWKEY C., CRAWFORD M., 1980. L'effet protecteur de l'acide $\alpha$-linolénique sur l'encéphalomalacie chez le Poulet. Ann. Nutr. Alim., 34, 389-400.

BUDOWSKI P., CRAWFORD M., 1985. $\alpha$-linolenic acid as a regulator of the metabolism of arachidonic acid : dietary implications of the ratio $n-6 / n-3$ fatty acids. Proc. Nutr. Soc., 44, 221-229.

COHEN S., BERNSOHN J., 1978. The in vivo incorporation of $\alpha$-linolenic acid into neuronal and glial cells and myelin. J. Neurochem., 30, 1327-1334.

CRAWFORD M., GALE M., WOUDFORD M., 1969. Linoleic acid and linolenıc acid elongation products in muscle tissue of Syncerus coffer and other ruminant species. Biochem. J., 115, 25-27. 
CRAWFORD M., WOODFORD M., 1971. Fatty acid composition in liver, aorta, skeletal and heart muscle of two free living ruminants. Int. J. Biochem., 2, 493-496.

CRAWFORD M., GALE M., WOODFORD M., 1970a. Muscle and adipose tissue lipids of the warthog, Phacochoerus aethiopicus. Int. J. Biochem., 1, 654-658.

CRAWFORD M., GALE M., WOODFORD M., CASPERD N., 1970b. Comparative studies on fatty acid composition of wild and domestic meats. Int. J. Biochem., 1, 295-305.

CRAWFORD M., HASSAM A., STEVENS P., 1981. Essential fatty acid requirement in pregnancy and lactation with special reference to brain development. Prog. Lipid Res., 20, 31-40.

DURAND G., PASCAL G., LEGRAND Ph., GOUNELLE DE PONTANEL H., 1985. Effets comparés d'huiles végétales et d'huiles de poisson sur la cholestérolémie du rat. Relations entre la composition en acides gras des lipides de la ration, celle des lipides sériques et la cholestérolémie. Méd. et Nutr., XXI, 391-406.

DYERBERG J., BANG H., HJORNE N., 1975. Fatty acid composition of the plasma lipids in Greenland eskimos. Am. J. clin. Nutr., 28, 958-966.

DYERBERG J., BANG H., STOFFERSEN E., MONCADA S., VANE J., 1978. Eicosapentaenoïc acid and prevention of thrombosis and atherosclerosis. Lancet, ii, 117-119.

EDDY D., HARMAN D., 1975. Rat brain fatty acid composition, effect of dietary fat and age. J. Geront., 30, 647-654.

FEHILY A., BURR M., PHILIPS K., DEADMAN N., 1983. The effect of fatty fish on plasma lipid and lipoprotein concentrations. Am. J. clin. Nutr., 38, 349-351.

FLIER J., LOKESH B., KINSELLA J., 1985. Increased $5^{\prime}$-nucleotidase activity in plasma membranes from rat liver following ingestion of fish oil. Nutr. Res., 5, 277-283.

FOLCH J., LEE M., SLOANE-STANDLEY G., 1957. A simple method for the isolation and purification of total lipids from animal tissue. J. biol. Chem., 226, 487-509.

FRANC̣OIS M., PASCAL G., DURAND G., 1980. Effets de la carence alimentaire en acide linolénique chez le rat. Ann. Nutr. Alim., 34, 443-450.

GALLI C., TRZCIAK H., PAOLETTI R., 1971. Effects of dietary fatty acids on the fatty acid composition of brain ethanolamine phosphoglyceride : reciprocal replacement of $n-6$ and $n-3$ polyunsaturated fatty acids. Biochim. Biophys. Acta, 248, 449-454.

GALLI C., AGRADI R., PAOLETTI R., 1974. The n-6 pentaene : $\mathrm{n}-3$ hexaene fatty acid ratio as an index of linolenic acid deficiency. Biochim. Biophys. Acta, 369, 142-145.

GALLI C., MESSERI G., OLIVERIO A., PAOLETII R., 1975. Deficiency of essential fatty acids during pregnancy and avoidance learning in the progeny. Pharmacol. Res. Commun., 7, 7180.

GANDEMER G., PASCAL G., DURAND G., 1980. Etude de la lipogenèse de novo : cinétique d'incorporation in vivo du ${ }^{3} \mathrm{H}$ de l'eau tritiée dans les acides gras et les lipides totaux du foie, du plasma, du tissu adipeux et de la carcasse du rat mâle. C. R. Acad. Sci. Paris, sér. D, 290 , 1479-1482.

GUDBJARNASON S., HALGRIMSSON J., 1976. The role of myocardial membrane lipids in the development of cardiac necrosis. Acta med. scand., 199, suppl. 587, 17-27.

GUESNET Ph., PASCAL G., DURAND G., 1986. Dietary $\alpha$-linolenic acid deficiency in the rat. I. Effects on reproduction and postnatal growth. Reprod. Nutr. Dévelop., 26, 969-985.

HARRIS W., CONNOR W., MCMURRY M.; 1983. The comparative reductions of the plasma lipids and lipoproteins by dietary polyunsaturated fats: salmon oil versus vegetable oils. Metabolism, 32, 179-184.

HOLMAN R., JOHNSON S., HATCH T., 1982. A case of human $\alpha$-linolenic acid deficiency involving neurological abnormalities. Am. J. clin. Nutr., 35, 617-623.

LAMPTEY S., WALKER B., 1978. Learning behaviour and brain lipid composition in rat subjected to essential fatty acid deficiency during gestation, lactation and growth. J. Nutr., 108, 358367.

MENON N., DHOPESHWARKAR G., 1981. Essential fatty acid deficiency and lipid metabolism of the developing brain. Prog. Lipid Res., 20, 129-134.

MENON N., DHOPESHWARKAR G., 1982. Essential fatty acid deficiency and brain development. Prog. Lipid Res., 21, 309-326.

MCMURCHIE E., RAISON J., 1979. Membrane lipid fluidity and its effect on the activation energy of membrane associated enzyme. Biochim. Biophys. Acta, 554, 364-374. 
NEEDLEMAN P., RAZ A., MINKES M., FERRENDELLI J., SPRECHER H., 1979. Triene prostaglandins : prostacyclin and thromboxane biosynthesis and unique biological properties. Proc. nat. Acad. Sci. USA, 76, 944-948.

NEURINGER M., CONNOR W., VAN PETTEN C., BARSTAD L., 1984. Dietary omega-3 fatty acid deficiency and visual loss in infant Rhesus monkeys. J. clin. Invest., 73, 272-276.

NEURINGER M., CONNOR W., LIN D., BARSTAD L., LUCK S., 1986a. Biochemical and functional effects of prenatal and postnatal $\omega 3$ fatty acid deficiency on retina and brain in rhesus monkeys. Proc. nat. Acad. Sci. USA, 83, 4021-4025.

NEURINGER M., CONNOR W., 1986b. n-3 fatty acids in the brain and retina : evidence for their essentiality. Nutr. Rev., 44, 285-294.

NORDOY A., 1965. The influence of saturated fats, cholesterol, corn oil and linseed oil on experimental venous thrombosis in rats. Thromb. Diath. Haemorrh., 13, 244-256.

NOUVELOT A., BOURRE J.-M., SEZILLE G., DEWAILLY P., JAILLARD J., 1983a. Changes in the fatty acid patterns of brain phospholipids during development of rats fed with peanut or rapeseed oil, taking into account differences between milk and maternal food. Ann. Nutr. Metabl., 27, 173-181.

NOUVELOT A., DEDONDER-DECOOPMAN E., SEZILLE G., PATURNEAU-JOUAS M., DUMONT O., MASSON M., BOURRE J.-M., 1983b. Influence de la teneur en acide linolénique du régime maternel sur la composition en acides gras polyinsaturés des fractions subcellulaires au cours du développement cérébral chez le rat. Ann. Nutr. Métabl., 27, 233-241.

NOUVELOT A., DEDONDER E., DEWAILLY Ph., BOURRE J.-M., 1985. Influence des acides gras $\mathrm{n}-3$ exogènes sur la composition en acides gras polyinsaturés de la rétine ; aspects structural et physiologique. Cah. Nutr. Diet, XX, 123-125.

PEIFER J., 1966. Hypocholesterolemic effects induced in the rat by specific types of fatty acid unsaturation. J. Nutr., 88, 351-358.

SETCHELL B., 1978. The mammalian testis, p. 3-93, Cornell Univ. Press, Ithaca, New York.

SIESS W., SCHERER B., BOHLIG B., ROTH O., KURZMANN I., WEBER P., 1980. Platelet membrane, fatty acids, platelet aggregation and thromboxane formation during a mackerel diet. Lancet, i, 441-444.

SINCLAIR A., CRAWFORD M., 1972. The accumulation of arachidonate and docosahexaenoate in the developing rat brain. J. Neurochem., 19, 1753-1758.

SINCLAIR A., CRAWFORD M., 1973. The effect of a low-fat maternal diet on neonatal rats. Br. J. Nutr., 29, 127-137.

SINCLAIR H., 1981. The relative importance of essential fatty acids of the linoleic and linolenic families; studies with an eskimo diet. Prog. Lipid Res., 20, 897-899.

SUN G., SUN A., 1974. Synaptosomal plasma membranes : acyl group composition of phosphoglycerides and $\mathrm{Na}^{+}, \mathrm{K}^{+}$ATPase activity during fatty acid deficiency. J. Neurochem., 22, 15-19.

SVENNERHOLM L., 1968 . Distribution and fatty acid composition of phosphoglycerides in normal human brain. J. Lipid Res., 9, 570-579.

TINOCO J., MILJANICH P., MEDWADOWSKI B., 1977. Depletion of docosahexaenoic acid in retinal lipids of rats fed a linolenic acid-deficient, linoleic acid-containing diet. Biochim. Biophys. Acta, 486, 575-578.

TINOCO J., BABCOK R., HINCERBERGS I., MEDWADOWSKI B., MILJANICH P., 1978. Linolenic acid deficiency : changes in fatty acid patterns in female and male rats raised on linolenic acid deficient diet for two generations. Lipids, 13, 6-17.

TINOCO J., BABCOCK R., HINCENBERGS B., MEDWADOWSKI B., 1979. Linolenic acid deficiency. Lipids, 14, 166-173.

TINOCO J., 1982. Dietary requirements and functions of $\alpha$-linolenic acid in animals. Prog. Lipid Res., 21, 1-45.

WHEELER T., BENOLKEN R., ANDERSON R., 1975. Visual membranes : specificity of fatty acid precursors for the electrical response to illumination. Science (Wash. D.C.), 188, 1312-1314.

WILLIAMSON D., 1980. Integration of metabolism in tissue of the lactating rat. FEBS Lett., 117 (suppl), K93-K105.

YOUYOU A., DURAND G., PASCAL G., PICIOTTI M., DUMONT O., BOURRE J.-M., 1986. Recovery of altered fatty acid composition induced by a diet devoid of $n-3$ fatty acids in myelin, synaptosomes, mitochondria and microsomes of developing rat brain. $J$. Neurochem., 46, 224-228. 